\title{
Evaluation of weed flora changes in Portugal in a 10 year basis
}

\author{
Sofia Ramôa ${ }^{1 *}$, Pedro Oliveira e Silva ${ }^{1}$, Ilias Travlos ${ }^{3}$, Teresa Vasconcelos ${ }^{2}$, Paulo Forte ${ }^{2}$, João \\ Portugal $^{1}$
}

\author{
1Instituto Politécnico de Beja, Escola Superior Agrária, Rua Pedro Soares, Apartado 6158, 7800-908 Beja, \\ Portugal \\ ${ }^{2}$ Universidade de Lisboa, Instituto Superior de Agronomia, Tapada da Ajuda, Apartado 354, 1349- 017 Lisboa, \\ Portugal \\ ${ }^{3}$ Agricultural University of Athens, Faculty of Crop Science, 75, Iera Odos str., GR11855, Athens, Greece
}

*Corresponding author: sramoa@ipbeja.pt

\begin{abstract}
The aim of this study was to assess the composition of weed communities starting from a rainfed farming system (1997), to the early period of transformation in agricultural systems with the adoption of irrigation (2007). The assessments were made within a 10-year interval and the floristic surveys were conducted in the same georeferenced plots. In 1997, the surveys were mostly performed in winter cereals (wheat, oat, barley), while in 2007, considering the same georeferenced plots, there were winter cereals and also irrigated olive groves, parcels of fallow, pasture and pine forest. Weed flora was determined by means of relative frequency, abundance and weed infestation degree. The effect of time was also evaluated by applying the methodology of variance analysis on the values of Shannon-Wiener Index. Canonical Correspondence Analysis was used to complement this information only for 2007 to know how the flora was distributed by the different cultures. Our results revealed that in both cases weed flora was of high diversity (229 and 264 species in 1997 and 2007, respectively), with the most representative families being always the same, namely Asteraceae, Poaceae and Fabaceae. The number of weeds that could be of concern for the farmers revealed to be relatively low. Our study confirmed that despite of the intensification of the agricultural production system, biodiversity increased over time. In both years, Lolium rigidum was present at high densities.
\end{abstract}

Keywords: Agroecosystems, weed infestation degree, Lolium rigidum, Mediterranean climate, plant biodiversity, multivariate analysis.

\section{Introduction}

Out of a large number only a few hundred weed species are important in agro-ecosystems. The ability of these weeds to compete with crops for water, light and nutrients is among the most important factors which determine the potential reduction of crop productivity. The potential losses of crop production caused by weeds can reach a global average of $38 \%$ (Vidal, 2010). The mechanisms available to weeds include - but not limited to - seed dormancy of different duration, high seed germination rate, environmental plasticity, high seedling growth and reproductive capacity, short life cycle, self-compatibility, efficient and well organized methods of seed dispersal, allelopathy and tolerance to abiotic and biotic stresses (Baker, 1974). Furthermore, weeds are able to survive and grow in different ecological habitats, with their occurrence being very sensitive to changes in agricultural practices (Fried et al., 2010; Petit et al., 2011). New agricultural management practices lead to new balances and such information is considered to be of major importance (José-María et al., 2010; Sans et al., 2013). Ecological services that this type of vegetation provides to the agro-ecosystems are not negligible. Wild plants often protect soil against water and wind erosion, which is especially important on slopes, where many perennial crops are planted. Natural vegetation also protects soil from mechanical compaction, while many of the weeds have medicinal and/or other value (Bilalis et al., 2014). In general, more intensive agriculture leads to lower biodiversity and reduces the environmental sustainability (Storkey and Westbury 2007; Stoate et al., 2009; José-María et al., 2010; Sans et al., 2013). Consequently, the maintenance of biodiversity in agro-ecosystems is considered to be of great importance in modern agriculture, based on economic, ecological and social parameters (Firbank et al., 2008). This kind of integrated weed management requires a detailed knowledge of the weed species (Johnson and Kent, 2002; Karar et al., 2005; Monteiro et al., 2012) and becomes relevant since it is one of the key steps for the development of sustainable weed management models.

The greatest European irrigation project, covering about 120000 ha of irrigated land is included into the Alqueva Multi-purpose Undertaking, located in south of Portugal, and has been accomplished in 2015 (EDIA, 2016). From its beginning in 2006 , there were profound changes in traditional farming systems in the region, traditionally based in rainfed cereal crops and, consequently, there has been diversification of cultural farmer's options. These changes are also linked to the adoption of a more intensive production model, which impact on natural resources should be well known in order to ensure the sustainable use of these new irrigated areas. Therefore, a very important issue is to evaluate the effect of 
time on composition of weed community, and its level of occurrence, in order to achieve an efficient weed management taking into account the ecological services that weeds render to the agro-ecosystems.

There are relatively few studies about weed flora based on long-term changes. Some of them are cited below and consider different periods of time and different perspectives which include changes in weed flora in arable fields (Table 1). The aim of this study was to assess the composition of weed communities and its occurrence in a 10-year interval considering 2007 the early stage of the transformations in agricultural systems that is taking place in south of Portugal. This study is the first of its kind carried out in Portugal, and it was conducted in order to evaluate the effect of time on weed species composition as the first part of a larger study which aims to study long-term changes (20-year interval). In the spring of 2017 new surveys will be done in the same georeferenced places with the irrigation project in full operation.

\section{Results and discussion}

\section{Weed surveys}

Weed surveys were conducted in south Portugal - Alentejo (Fig. 1), in two years, 1997 and 2007. In 2007, about 10\% of the studied sites started to have irrigated crops, especially olives.

\section{Weed vegetation composition and diversity}

In 1997, 229 species were identified and distributed over 40 families, increasing their number in 2007 , where 264 species were identified and distributed among 43 families. Our results are in accordance with previous studies conducted in the Mediterranean region, verifying always high weed diversity: 175 species in 138 surveys conducted by Cirujeda et al. (2011) in Spain and 278 species in 86 surveys in Greece (Damanakis, 1983). These numbers are significantly higher compared with those found in the north and central Europe (Holzner and Immonen, 1982; Chancellor and FroudWilliam, 1984; Sutcliffe and Kay 2000; Salonen et al., 2001). The botanical families with greater representation were the same in both periods, and also with similar representation (of about 50\%): Asteraceae followed by Poaceae and Fabaceae. These families have been the most common ones in previous studies carried out in the central region of Portugal on vineyard (Monteiro et al., 2012) and maize (Calha et al., 2014).

In 1997, the following seven species were identified in more than 50\% of the surveys: Avena sterilis, Anagallis arvensis, Convolvulus arvensis, Lolium rigidum, Phalaris minor, Polygonum aviculare and Raphanus raphanistrum. In 2007, only three species were identified, namely Avena sterilis, Lolium rigidum and Phalaris minor. These findings are similar to those observed for the most frequent species identified in Spain by Cirujeda et al. (2011), namely $L$. rigidum and A. sterilis. According to Ramôa et al. (2015), soil texture and soil phosphorus content had a significant effect on the species distribution. In particular, L. rigidum seems to be associated with medium soil texture and $A$. sterilis also showed a preference for medium and fine soil texture soils. The distribution of $P$. minor was not related to the soil texture but it showed preference for soils with medium phosphorus content.
As shown in Table 2, L. rigidum was the only species with a very high weed infestation degree in both study periods.

In 1997, a total of the following eight species showed a high level of weed infestation degree: A. arvensis, Galium aparine, Lolium temulentum, Oxalis pes-caprae, $P$. minor, $P$. aviculare, Ranunculus trilobus and $R$. raphanistrum. In 2007, the following 14 species showed high infestation degree: Agrostis pourretii, A. sterilis, Carthamus lanatus, Chamaemelum mixtum, Crepis vesicaria, Cynodon dactylon, Bromus hordeaceus, Galium aparine, Hirschfeldia incana, Juncus bufonius, Leotondon taraxacoides, Stipa capensis, Trifolium campestre and Vulpia ciliata. Regarding $L$. rigidum, it has been found in several other places as a very common and abundant species (Recasens et al., 1996; Cirujeda et al., 2011; Borger et al., 2012; Monteiro et al., 2012). Armengot et al. (2011) indicated that species like $L$. rigidum are closely linked to intensified agricultural practices. According to Sans et al. (2013), the high pressure of herbicides can lead to resistant species, reduction of the dicotyledonous and increase of the monocotyledonous species, such as L. rigidum, A. sterilis and P. minor. Another noteworthy finding is related to the small number of problematic species (which could be considered as weeds of agronomic importance), compared to the total number of identified species. This fact is in accordance with previous findings of Borger et al. (2012) in Australia.

\section{Trend over time}

Table 3 shows the statistically significant increase of the Shannon index over time, which confirms the higher plant biodiversity in 2007 compared with 1997.

The CCA analysis shows the distribution pattern of biodiversity and its relationship to the different crops. The values of the inflation factor of variance (VIF), taking into consideration all the variables involved, are shown in Table 4. The results shown in Table 4 revealed no statistical correlations between the variable crops. The pine forest revealed a value very close to 1 , indicating that it was an independent variable. Canonical Correspondence Analysis (CCA) revealed significant community differences among weed crop's species (Table 5 and Fig. 2). Nearly $10.5 \%$ of the species variability was explained by the different crops. The percentages of accumulated variation explained by the species and crops, from the first to the third CCA axes, were $34.4 \%, 51.9 \%, 66 \%$, respectively and in all cases statistically significant. This means that the constrained ordination did not explain $34 \%$ of the remaining variability. Moreover, ANOVA test also indicated that the extraction of the first two axes revealed significant.

Based on Canonical Correspondence Analysis (Table 5), it was verified that both fallow and pasture flora were positively related to axis 1 while wheat, barley and oat had a negative related with this axis, indicating differences in flora composition. Between the factors that presented significant differences, pasture $(\mathrm{p}<0.001)$ had the largest weight $\left(\mathrm{R}^{2}=\right.$ 0.512 ). These results revealed clear differences in the flora between rainfed cereals and fallow or pasture areas. In the case of oat there were also some significant differences and studied flora was significantly affected $\left(R^{2}=0.236\right)$. These differences may be attributed at differences in weed control. Oat has a reduced (or even absent) weed control comparing with wheat and barley (where herbicide application is common), once its production is devoted to livestock feed. In addition, in fallow and pasture areas, no weed control is 
Table 1. Information about some weed flora studies based on long-term changes.

\begin{tabular}{|c|c|c|}
\hline Reference & Year period & Country \\
\hline Rademacher et al. (1970) & $1956-1968$ & Germany \\
\hline Sutcliffe and Kay (2000) & early 1960 s - 1997 & England \\
\hline Lososová et al. (2004) & $1954-2003$ & Czech Republic and Slovakia \\
\hline Baessler and Klotz (2006) & $1957-2000$ & Germany \\
\hline Peter (2007) & $1975-2004$ & Switzerland \\
\hline Firbank et al. (2008) & $\begin{array}{l}\text { An overview about pressures of agricultural change on } \\
\text { biodiversity }\end{array}$ & Bristish perspective \\
\hline Roitman et al. (2008) & $1991-2004$ & Brazil \\
\hline Stoate et al. (2009) & An overview of the ecological status of agricultural systems & $\begin{array}{l}\text { European Union: UK, The Netherlands, Boreal } \\
\text { and Baltic countries, Portugal, Hungary and } \\
\text { Romania, }\end{array}$ \\
\hline Fried et al. (2009) & $1970-2000$ & France \\
\hline $\begin{array}{l}\text { Andreasen and Streibig } \\
(2010)\end{array}$ & $1967-2007$ & Denmark \\
\hline Wang et al. (2011) & Prior to $1949-2010$ & Australia \\
\hline Borger et al. (2012) & $1997-2008$ & Australia \\
\hline Salonen et al. (2012) & $1997-2009$ & Finland \\
\hline Fried et al. (2012) & 1973, 1976 and $2003-2006$ & France \\
\hline Kolárová et al. (2013) & $2006-2008$ & Czech Republic. \\
\hline Meyer et al. (2013) & $1950 s / 60 s-2009$ & Germany \\
\hline $\begin{array}{l}\text { Alignier and Baudry } \\
(2015)\end{array}$ & $1995-2013$ & France \\
\hline
\end{tabular}

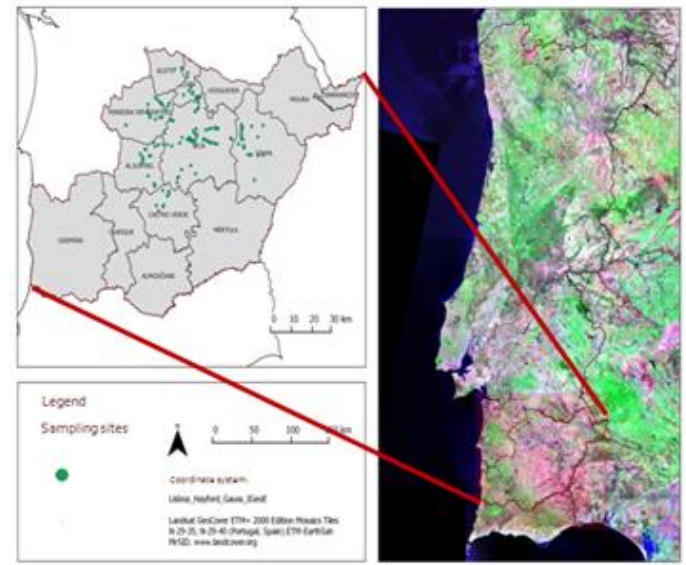

Fig 1. Location of the surveys in the Alentejo region - Portugal.

Table 2. Weed infestation degree.

\begin{tabular}{lll}
\hline Weed infestation degree & 1997 & 2007 \\
\hline Very high & Lolium rigidum & Lolium rigidum \\
\hline & Anagallis arvensis & Agrostis pourretii \\
& Galium aparine & Avena sterilis \\
& Lolium temulentum & Carthamus lanatus \\
High & Oxalis pes-caprae & Chamaemelum mixtum \\
& Phalaris minor & Crepis vesicaria \\
& Polygonum aviculare & Cynodon dactylon \\
& Ranunculus trilobus & Bromus hordeaceus \\
& Raphanus raphanistrum & Galium aparine \\
& & Hirschfeldia incana \\
& & Juncus bufonius \\
& & Leontodon taraxacoides \\
& & Stipa capensis \\
& Trifolium campestre \\
\hline
\end{tabular}




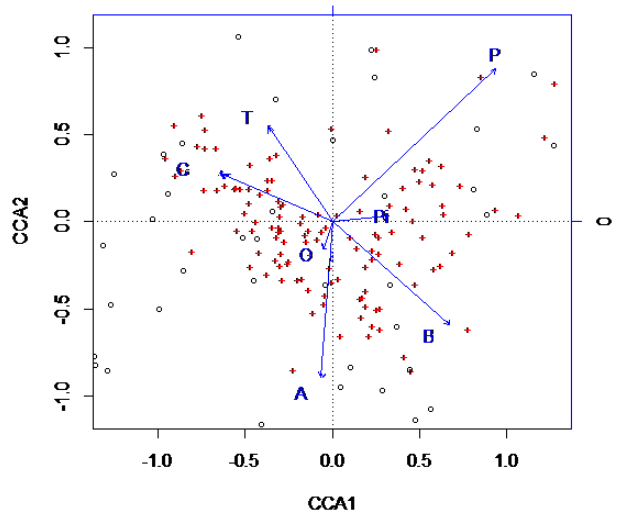

Fig 2. Triplot graph of CCA. (P: pasture; B: fallow; Pi: pine forest; T: wheat; C: barley; A: oat; O: olive grove).

Table 3. Time effect on weed flora.

\begin{tabular}{lllll}
\hline Time & Shannon-Wiener index* & Standard error & Tukey test & \\
\hline 1997 & 2.8700 & 0.0487 & $\mathrm{~b}$ & $\mathrm{CV}=16.1 \%$ \\
2007 & 3.0257 & 0.0464 & $\mathrm{a}$ & \\
\hline *mean values & & & &
\end{tabular}

Table 4. Values of the inflation factor of variance (VIF).

\begin{tabular}{llllllll}
\hline Year & T & A & C & B & O & P & Pi \\
\hline 2007 & 2.405 & 2.210 & 2.131 & 3.118 & 1.727 & 1.623 & 1.127 \\
\hline T: wheat; A: oat; C: barley; B: fallow; O: olive grove; P: pasture; Pi: pine forest. & & & & &
\end{tabular}

Table 5. Results of CCA analysis.

\begin{tabular}{|c|c|c|c|c|c|c|}
\hline & $\mathrm{CCA}_{1} * *$ & $\mathrm{CCA}_{2} * *$ & It & Ic & $\mathrm{R}^{2}$ & $\mathbf{F}$ \\
\hline $\begin{array}{l}\text { Cumulative percentage of variance explained from } \\
\text { species } \times \text { crops }(\%)\end{array}$ & 34.4 & 51.9 & 5.373 & 0.566 & & \\
\hline Wheat & -0.249 & 0.372 & & & 0.105 & $*$ \\
\hline Oat & -0.048 & -0.612 & & & 0.236 & $* * *$ \\
\hline Barley & -0.443 & 0.193 & & & 0.116 & $* *$ \\
\hline Olive grove & -0.037 & -0.115 & & & 0.010 & ns \\
\hline Fallow & 0.460 & -0.406 & & & 0.186 & $* * *$ \\
\hline Pasture & 0.643 & 0.602 & & & 0.512 & $* * *$ \\
\hline Pine forest & 0.221 & 0.024 & & & 0.028 & ns \\
\hline
\end{tabular}

Table 6. Criteria for assessing weed infestation degree.

\begin{tabular}{cccc}
\hline Abundance & \multicolumn{4}{c}{ Relative frequency $(\%)$} \\
coefficients & $<25$ & $25-50$ & $>50$ \\
\hline $\mathbf{1}$ & $\mathbf{0}$ & + & \\
$\mathbf{2}$ & + & ++ & \\
$\mathbf{4}$ & & & \\
$\mathbf{5}$ & & +++ & ++++ \\
\hline
\end{tabular}

0 very low; + low; ++ medium; +++ high; ++++ very high.

performed and consequently very diverse weed flora is present, probably because of the rich soil seed bank and the potential inclusion of leguminous species in sown pastures (Travlos, 2010). Olive groves and pine forest had no significant effect on weed diversity due to their low representation compared with the other crops.

Several studies have shown that the intensification of crops, due to the availability of irrigation, leads to a decrease in biodiversity (Storkey and Westbury, 2007; José-María et al., 2010; Plaza et al., 2011; Sans et al., 2013). However, in the present study, an increase of total plant diversity was observed. This could be attributed to the establishment of new and diverse crops and, the low percentage (10\%) of irrigated crops in 2007. Besides, the fallow areas were significant in number, which may explain this fact, since they are particularly rich in weed flora (Robleño et al., 2013).
Sown pastures also revealed high floristic richness and abundance by having a large supply of seeds in the soil (Sans et al., 2013).

According to Plazza et al. (2011), it is necessary to conduct new studies on dynamics of vegetation using longer periods of time. This is justified by the high persistence of seeds in soil working as a population buffer against environmental changes (Légère et al., 2005).

\section{Materials and Methods}

\section{Weed survey and data collection}

This project began in 1997 with the objective of knowing the composition of weed communities for a better weed management in rainfed arable crops. At the same time, 
Alqueva dam was in construction. So, in 1997, the plots were randomly selected taking into account only those with rainfed winter cereal crops and the surveys were made in the future zones of influence of the Alqueva Multi-purpose Undertaking basin. At that time, 100 floristic surveys were done, mainly in wheat but also in oat and barley plots. The surveyed plots were all referenced with GPS using the Quantum GIS version 1.8.0 program (2011) for setting them in the Administrative Official Map of Portugal - Beja district. Ten years later, in 2007, 105 floristic surveys were performed exactly in the same georeferenced places. We found plots with wheat, oat, barley and new ones containing irrigated olive groves, pine forest, fallow and pasture, recently established as a result of the new irrigated areas. The surveys were conducted on April and May, walking around the field in a random way until no new species were detected (Vasconcelos et al., 1999; Cirujeda et al., 2013).

Then, a list of presence and absence of species was created, in which the latin name and the EPPT code (European and Mediterranean Plant Protection Thesaurus) were added. Species' abundance was estimated as proposed by Barralis (1975, 1976) and also used by Monteiro et al. (2012), considering the following abundance coefficients: 1 (abundance less than 1 individual per $\mathrm{m}^{2}$ ), 2 (abundance 1-2 individuals per $\mathrm{m}^{2}$ ), 3 (abundance 3-20 individuals per $\mathrm{m}^{2}$ ), 4 (abundance 21-50 individuals per $\mathrm{m}^{2}$ ), 5 (abundance higher than 50 individuals per $\mathrm{m}^{2}$ ). Weed infestation degree due to the relative frequency and average abundance was determined, according to Monteiro et al. (2012) and is shown in Table 6 . These procedures were identical for both years. Table 6 - Criteria for assessing weed infestation degree.

\section{Data analysis}

In order to assess changes in weed flora over time, the methodology of analysis of variance (ANOVA) was used to the values of Shannon-Wiener Index over time, according to a completely randomized outline. The differences between the average values of the studied factors (time and diversity) and their interaction were considered significant for a significance level of $p<0.05$. Tukey's test for levels of significance $p=0.05$ was used in cases that the analysis of variance revealed a significant effect for the analyzed factors or their interaction, in order to identify differences between average values.

Multivariate analysis methodology and particularly Canonical Correspondence Analysis (CCA) was used to complement gathered information. For processing data RProject for Statistical Computing software was used ( $R$ Development Core Team, 2011), with Vegan package (Oksanen et al., 2013). The methodology is described in general terms according to Kindt and Coe (2005) and Oksanen et al. (2013). Canonical Correspondence Analysis (CCA) was used only for the year 2007 to examine flora and the different crops. Before running the program, the species whose relative frequency values were $\leq 10 \%$ were removed from the original file. Only then, the CCA was performed, scaling 2 analyses with all the independent variables (types of crops and other forms of land use) to get the relation with weed flora. The values of the inflation factor of variance (VIF) were calculated in order to eliminate previously independent and highly correlated variables (VIF $\geq 10$ ).

\section{Conclusion}

Our survey revealed that the main botanical families that have been maintained over time were the same, namely
Asteraceae, Poaceae and Fabaceae. The numbers of identified taxa were always very high, although most species showed low frequency and abundance values. Only a small group of species, in both years, showed levels of frequency and abundance that should concern the farmers. Lolium rigidum revealed to have very high degree of infestation in both periods of time. In 2007, weed flora was more abundant in species richness. Gradual changes in farming systems traditionally practiced in the region, driven by the introduction of irrigation are partially responsible for the observed differences. Moreover, new areas of olive groves which are associated with more intensive agriculture techniques and different pressure on the environment have probably created favorable conditions for the emergence of weeds. In addition, the long-term impact because of the EU policies regarding the implementation of the set-aside, subsidized crops (including areas of pasture and fallow) had a great expression in Alentejo. Fallows and pastures are particularly rich in weeds, which are integrated in certain areas as greening policies in order to increase biodiversity. Consequently, such surveys should be further conducted and progressive changes in weed flora like the ones observed in the present study ought to be taken into account for the development of an efficient and tailor-made weed management system.

\section{References}

Alignier A, Baudry J (2015) Changes in management practices over time explain most variation in vegetation of field margins in Brittany, France. Agric Ecosyst Environ. 211: 164-172.

Andreasen C, Streibig JC (2010) Evaluation of changes in weed flora in arable fields of Nordic countries - based on Danish long term survey. Weed Res. 51: 214-226.

Armengot L, José-Maria L, Blanco-Moreno M, RomeroPuente A, Sans FX (2011) Landscape and land-use effects on weed flora in Mediterranean cereal fields. Agric Ecosyst Environ. 142(3-4): 311-317.

Baker H (1974) The evolution of weeds. Annu Rev Ecol Syst. 5: 1-24.

Barralis G (1975) Résultats d'une enquête sur la repartition et la densité des mauvaise herbes en France. Paper presented in $8^{\text {ème }}$ Conférence du Columa. 4: 1042-1058.

Barralis G (1976) Méthode d'étude des groupements adventices des cultures annuelles à la Côte d Or. $5^{\text {ème }}$ Coll Int Ecol Biol Mauvaises Herbes. 1: 59-68.

Baessler C, Klotz S (2006) Effects of changes in agricultural land-use on landscape structure and arable weed vegetation over the last 50 years. Agric Ecosyst Environ. 115: 43-50.

Bilalis DJ, Travlos IS, Papastylianou P (2014). Natural vegetation as a key to sustainability of agroecosystems. In: Zorpas AA (ed) Sustainability behind sustainability. Nova Science Publishers Inc, Hauppauge, New York. 9.

Borger CPD, Michael PJ, Mandel R, Hashem A, Bowran D, Renton M (2012) Linking field and farmer surveys to determine the most important changes to weed incidence. Weed Res. 52(6): 564-574.

Calha IM, Sousa E, González-Andújar JL (2014) Infestation maps and spatial stability of main weed species in maize culture. Planta Daninha. 32(2): 275-282.

Chancellor RJ, Froud-Williams RJ (1984) A second survey of cereal weeds in central southern England. Weed Res. 24(1): 29-36.

Chancellor RJ (1985) Changes in the weed flora of an arable field cultivated for 20 years. J Appl Ecol. 22(2): 491-501. 
Cirujeda A, Aibar J, Zaragoza C (2011) Remarkable changes of weed species in spanish cereal fields from 1976 to 2007. Agron Sustain Dev. 31(4): 675-688.

Cirujeda A, Marí A, Murrilo S, Aibar J, Zaragoza C (2013) La flora arvense en el cultivo de la esparceta (Onobrychis viciifolia L.) aumenta la biodiversidade vegetal. Paper presented in XIV Congreso de la Sociedad Española de Malherbologia, Valência, Spain. 31-35. 5-7 November.

Damanakis M (1983) Weed species in wheat fields of Greece - 1982, 1983 survey. Zizaniology. 1: 85-90.

EDIA - Empresa de desenvolvimento e infra-estruturas do Alqueva (2016) Available: http://www.edia.pt. (accessed 2016 December).

Firbank LG, Petit S, Smart S, Blain A, Fuller RJ (2008) Assessing the impacts of agricultural intensification on biodiversity: a British perspective. Philos Trans R Soc Lond B Biol Sci. 363(1492): 777-787.

Fried G, Chauvell B, Reboud X (2009) A functional analysis of large-scale temporal shifts from 1970 to 2000 in weed assemblages of sunflower crops in France. J Veg Sci. 20: 49-58.

Fried G, Petit S, Reboud X (2010) A specialist-generalist classification of the arable flora and its response to changes in agricultural practices. BMC Ecol. 10(1): 20.

Fried G, Kazakou E, Gaba S (2012) Trajectories of weed communities explained by traits associated with species'response to management practices. Agric Ecosyst Environ. 158: 147-155.

Hiltbrunner J, Scherrer C, Streit B, Jeanneret P, Zihlmann U, Tschachtli R (2008) Long-term weed community dynamics in Swiss organic and integrated farming system. Weed Res. 48: $360-369$.

Holzner W, Immonen R (1982) Europe: an overview. In: Holzner W and Numata M (ed). Biology and Ecology of Weeds. Junk, The Hague, Netherlands.

Johnson DE, Kent RJ (2002) The impact of cropping on weed species composition in rice after fallow across a hydrological gradient in west Africa. Weed Res. 42(2): 8999.

José-María L, Armengot L, Blanco-Moreno JM, Bassa M, Sans X (2010) Effects of agricultural intensification on plant diversity in Mediterranean dry land cereal fields. $\mathbf{J}$ Appl Ecol. 47(4): 832-840

Karar RO, Mohamed BF, Marrs RH (2005) Factors influencing the weed flora in Gezira Scheme, Sudan. Weed Res. 45(2): 121-129.

Kindt R, Coe R (2005) Tree diversity analysis. A manual and software for common statistical methods for ecological and biodiversity studies. (ed) World Agroforestry Centre (ICRAF). Nairobi, Kenya.

Kolárová M, Tyser L, Soukup S.(2013) Impact of site conditions and farming practices on the occurrence of rare and endangered weeds on arable land in the Czech Republic. Weed Res. 53(6): 489-498.

Légère A, Stevenson FC, Benoit DL (2005) Diversity and assembly of weed communities: contrasting response across cropping systems. Weed Res. 45(4): 303-315.

Lososová Z, Chytrý M, Cimalová S, Kropác Z, Otýpková Z, Pysek P, Tichý L (2004) Weed vegetation of arable land in Central Europe: Gradients of diversity and species' composition. J Veg Sc. 15: 415-422.

Mas MT, Verdú AMC (2003) Tillage system effects on weed communities in a 4 year crop rotation under Mediterranean dryland conditions. Soil Tillage Res. 74: 15-24

Meyer S, Wesche K , Krause B, Leuschner C (2013) Dramatic losses of specialist arable plants in Central
Germany since the 1950s/60s - a cross-regional analysis. Diversity Distrib. 19: 1175-1187.

Monteiro A, Caetano F, Vasconcelos T, Lopes CM (2012) Vineyard weed community dynamics in the Dão winegrowing region. Ciência Técnica e Vitivinícola. 27(2): 73-82.

Oksanen J, Blanchet FG, Kindt R, Legendre P, O'Hara RB, Simpson GL, Solymos P, Stevens MHH, Wagner H (2013) Vegan tutorial: Community Ecology Package. R package version 1.17-6. http://CRAN.R-project.org/package=vegan

Peter M (2007) Changes in the floristic composition of seminatural grasslands in the Swiss Alps over the last 30 years. Dissertation submitted to the Swiss Federal Institute of Technology Zurich for the degree of Doctor of Sciences. Zurich.

Petit S, Boursault A, Guilloux M, Munier-Jolain N, Reboud $X$ (2011) Weeds in agricultural landscapes. A review article. Agron Sustain Dev. 31(2): 309-317.

Plaza EH, Kozak M, Navarrete L, Gonzalez-Andújar JL (2011) Tillage system did not affect weed diversity in a 23 year experiment in Mediterranean dryland. Agric Ecosyst Environ. 140(1-2): 102-105.

Potts GR, Ewald JA, Aebischer NJ (2010) Long-term changes in the flora of cereal ecosystem on the Sussex Downs, England, focusing on the 1968-2005. J Appl Ecol. 47(1): 215-226.

Quantum GIS version 1.8.0 (2011) Software SIG (Sistema de informacção geográfica) open source. Available: http://www.qgis.org/ ( accessed 2011 October).

Ramôa S, Oliveira e Silva P, Vasconcelos T, Fortes P, Portugal J (2015) Study of autumn-winter weeds in Portugal and its ecological preferences. Planta Daninha. 33(3): 387-394.

R Development Core Team (2011) R: A language and environment for statistical computing. $\mathrm{R}$ foundation for statistical computing, Vienna, Austria. ISBN 3-900051-070, URL http://www.R-project.org/

Rademacher B, Koch W, Hurle K (1970) Changes in the weed flora as a result of continuous cropping of cereals and annual use of the same weed control measures since 1956. Proceedings of the British Crop Protection Council. 10: 16

Recasens J, Riba F, Izquierdo J, Forn R, Taberner A (1996) Grass weeds growing in winter cereals of Catalonia. ITEA Producción vegetal. 92(2): 116-130.

Robleño I, Solé X, Royo-Esnal A, Torra T, Conesa JA, Recasens J (2013) El manejo de barbechos como indicador de la eficiencia de medidas agroambientales en secanos cerealistas. Paper presented in XIV Congreso de la Sociedad Española de Malherbologia, Valência, Spain. 5-7 November.

Roitman I, Felfili J M, Rezende A V (2008) Tree dynamics of a fire-protected Cerrado sensu stricto surrounded by forest plantations, over a 13-year period (1991-2004) in Bahia, Brazil. Plant Ecol. 197(2): 255-267.

Salonen J, Hyvönen T, Jalli H (2001) Weeds in spring cereal fields in Finland - a third survey. Agric Food Sci Finland. 10: $347-364$.

Salonen J, Hyvönen T, Kaseva J, Jalli H (2012) Impact of changed cropping practices on weed occurrence in spring cereals in Finland - a comparison of surveys in 1997-1999 and 2007-2009. Weed Res. 53(2): 110-120.

Sans FX, Armengot L, Bassa M, Blanco-Moreno JM, Caballero-López L, Chamorro L, José-Maria L. (2013) La intensificación agrícola y la diversidad vegetal en los sistemas cerealistas de secano mediterráneos: implicaciones para la conservación. Ecosistemas. 22(1): 30-35. 
Stoate C, Báldi A, Beja P, Boatman ND, Herzon I, van Doorn A, de Snoo GR, Rakosky L, Ramwell C (2009) Ecological impacts of early $21^{\text {st }}$ century agricultural change in europe - A review. J Environ Manag. 91(1): 22-46.

Storkey J, Westbury DB (2007) Mini-review. Managing arable weeds for biodiversity. Pest Manag Sci. 63(6): 517523.

Sutcliffe OL, Kay QON (2000) Changes in the arable flora of central southern England since the 1960s. Biol Conserv. 93(1): 1-8.

Travlos IS (2010) Legumes as cover crops or components of intercropping systems and their effects on weed populations and crop productivity. In: Greco AJ (ed) Advances in Food Science and Technology. Nova Science Publishers Inc, Hauppauge, New York. Vol.1, 151-164 p.

Vasconcelos T, Tavares M, Gaspar N (1999) Aquatic plants in the rice fields of the Tagus valley, Portugal. Hydrobiología. 415: 59-65.
Vidal R (2010) Interação Negativa entre Plantas: Inicialismo, Alelopatia e Competição. Porto Alegre: Evangraf. Brazil. 130

Wang J, Eyre TJ, Neldner VJ, Bean T (2011) Floristic composition and diversity changes over 60 years in eastern mulga communities of south central Queensland, Australia. Biodivers Conserv. 20(12): 2759-2778. 